Journal Economics and Management (JECMA)

Volume 03, No. 01, Agustus 2021, p. 1-9

\title{
Pengaruh Kualitas Pelayanan dan Kualitas Produk terhadap Kepuasan Konsumen Bank BTN Cabang Tegal
}

\author{
The Influence of Service Quality and Product Quality on Customer Satisfaction of \\ Bank BTN, Tegal Branch

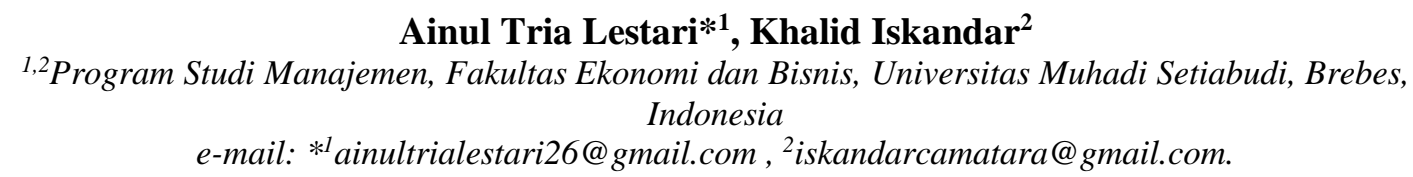

\begin{abstract}
ABSTRAK
Tujuan penelitian untuk mengetahui pengaruh dari kualitas pelayanan dan produk terhadap kepuasan konsumen bank BTN Cabang Tegal. Metode pengambilan data dengan cara memberikan kuisoner kepada konsumen bank BTN Cabang Tegal secara acak baik yang dilakukan dengan metode online (google form). Data terdiri dari 80 responden. Teknik analisis data dilakukan dengan populasi dan sampel secara acak pada konsumen bank BTN Cabang Tegal. Kemudian diuji menggunakan teknik regresi linear sederhana melalui program spss. Berdasarkan hasil penelitian melalui SPSS, dimulai dari uji validitas, reliabilitas, uji hipotesis $(t)$ dan analisis regresi berganda $(f)$. Nilai signifikasi dari hasil uji $T$ dan uji $F$ sebesar 0,000 <0,05. Berkaitan dengan hal tersebu, maka dapat disimpulkan bahwa terdapat pengaruh kualitas pelayanan dan produk $(X)$ terhadap kepuasan konsumen $(Y)$.

Kata kunci: Kualitas Pelayanan, Kualitas Produk dan Kepuasan Konsumen.
\end{abstract}

\begin{abstract}
The purpose of the study was to determine the effect of service and product quality on customer satisfaction at Bank BTN Tegal Branch. The method of data collection is by giving questionnaires to customers of Bank BTN Tegal Branch at random either by using the online method (google form). The data consists of 80 respondents. The data analysis technique was carried out with a population and a random sample on the consumers of the bank BTN Tegal Branch. Then tested using a simple linear regression technique through the SPSS program. Based on the results of research through SPSS, starting from the validity, reliability, hypothesis testing $(t)$ and multiple regression analysis $(f)$. The significance value of the results of the $T$ test and $F$ test is $0.000<0.05$. In this regard, it can be concluded that there is an effect of service and product
\end{abstract} quality $(X)$ on consumer satisfaction $(Y)$.

Keywords: Service Quality, Product Quality and Consumer Satisfaction

\section{INTRODUCTION}

Bank merupakan lembaga yang dipercaya pemerintah dalam bertindak sebagai mediator antara pihak disponsori dan berperan dalam departemen yang kekurangan dana. Sebagai wali amanat pemerintah, badan tersebut memiliki aturan dan peraturan yang lebih ketat untuk operasinya. , Seperti dengan kegiatan lainnya. Perbankan sebagai lembaga keuangan yang mengembangkan usahanya juga menghadapi masalah-masalah umum yang secara alamiah mempengaruhi sektor korporasi. Oleh karena itu, peran bank dalam industri jasa sangat penting. Berperan penting dalam tingkatkan kualitas pelayanan dan kepuasan pelanggan. Faktor-faktor yang mempengaruhi kualitas pelayanan perlu dipahami bank. Tujuan dari penelitian ini adalah menganalisis dampak bukti fisik (tangible) dan jaminan (dan sebaliknya) serta keamanan, efisiensi, keandalan cabang BTN Tegal Segundo dan dampaknya terhadap kepuasan nasabah, analisis faktor kepuasan nasabah bank. Selain itu, loyalitas pelanggan survei dilakukan di kantor BTN Tegal.

Submitted: Juli 2021, Accepted: Agustus 2021, Published: Agustus 2021 ISSN: 2746-0568 (online), Website: http://jurnal.umus.ac.id/index.php/jecma 
Journal Economics and Management (JECMA), Volume 03, No. 01, Agustus 2021, p. 1-9

Berdasarkan Undang-Undang Nomor 19 Tahun 2003, Badan Usaha Milik Negara (BUMN) atau EPE adalah badan usaha dengan modal dimiliki oleh negara dan berasal dari kekayaan milik negara yang terpisah. Pengelolaan keuangan badan usaha milik negara tidak tergantung pada laporan keuangan pemerintah pusat. Saat ini, BUMN memiliki banyak bentuk, termasuk perseroan terbatas (Persero), dimana modal dibagi menjadi saham, dan Republik Indonesia memiliki seluruh atau setidaknya 51\% saham. Selain itu, BUMN dapat berbentuk perusahaan terbuka disebut Persero Umum yaitu Persero dengan modal dan jumlah pemegang sahamnya memenuhi standar atau dijual kepada publik sesuai ketentuan pasar modal dan peraturan. Secara umum, BUMN dapat berbentuk perusahaan saham disebut Perum. Hal ini berarti BUMN dengan modal yang dimiliki oleh negara dan tidak terbagi atas saham yang melayani kepentingan umum dalam bentuk surat berharga yang bermutu tinggi. Barang atau jasa untuk mencari jasa berdasarkan prinsip komersial.

Kualitas pelayanan berusaha untuk memenuhi kebutuhan dan keinginan pelanggan, dan untuk memastikan pengiriman dengan tetap mempertimbangkan keinginan konsumen. Keunggulan pelayanan didefinisikan sebagai jenis atau sikap karyawan yang memberikan pelayanan pelanggan/pelanggan yang memuaskan. Akurasi, keramahan dan kenyamanan secara keseluruhan. Manajemen secara keseluruhan merupakan 4 pilar konsep kualitas. Manajemen mutu merupakan pelayanan berupa jasa maupun produk yang dapat diberikan oleh konsumen/pembeli. Penerapan TQM di bank pelayanan adalah untuk memberikan pelayanan berkualitas tinggi [1].

Kualitas produk itu merupakan karakteristik umum kemampuan produk atau jasa dalam rangka pemenuhan kebutuhan eksplisit atau implisit. Ada 8 (delapan) area yang mendefinisikan kualitas produk yang dapat dijadikan standar pengukuran, yaitu: performance, performance, reliability, compliance, Durability, Usability, Estetika, dan Perceived Quality. Jika konsumen menganggap parameter-parameter tersebut baik, mereka menganggap produk tersebut berkualitas baik, sebaliknya jika mereka menganggap banyak parameter produk tidak baik, mereka menganggap produk tersebut buruk.

Kepuasan pelanggan adalah tugas utama yang tidak dapat diabaikan oleh setiap bisnis perbankan. Karena kepuasan pelanggan merupakan aspek penting dalam menjaga citra sosial perusahaan secara keseluruhan, maka perlu untuk meningkatkan kualitas pelayanan kepada pelanggan. Peningkatan kualitas pelayanan pelanggan sangat penting untuk meningkatkan kepuasan pelanggan, yang sangat penting karena peran penting pelanggan dipandang sebagai kontribusi langsung atau tidak langsung terhadap penjualan untuk menjaga vitalitas perusahaan. Karena Setiap organisasi mempunyai harapan yang besar agar pegawai dapat meningkatkan kinerja yang terbaik. Karena Kinerja merupakan unsur dari kesuksesan individu dalam melakukan suatu pekerjaan [2].

Dalam industri perbankan, kepuasan nasabah diutamakan. Mengenai tingkat kesenangan pelanggan adalah aspek penting dalam menjaga citra sosial perusahaan, maka perlu dilakukan peningkatan kualitas pelayanan kepada pelanggan. Meningkatkan kualitas Pelayanan pelanggan sangat penting untuk peningkatkan kepuasan pelanggan. Hal ini sangat perlu untuk pelanggan dalam memberikan kontribusi pendapatan untuk mempertahankan eksistensi perusahaan. Kepuasan pelanggan adalah indikator terpenting loyalitas dari pelanggan. Kepuasan pelanggan dengan pelayanan BTN akan menerjemahkan perasaan ini menjadi loyalitas. Seiring waktu, pelanggan dapat menjadi loyal [3]. Meningkatkan kepuasan atau ketidakpuasan pelanggan. Kepuasan pelanggan dapat membawa banyak manfaat, antara lain terdapat hubungan perusahaan 
Journal Economics and Management (JECMA), Volume 03, No. 01, Agustus 2021, p. 1-9

dengan pelanggan yang harmonis, yang meletakkan dasar pembelian ulang dan loyalitas pelanggan, benar-benar memenuhi harapan mereka dan mempengaruhi kepuasan pelanggan [4].

Uraian ini berarti bahwa kualitas pelayanan, manfaat pelanggan dan kualitas produk dapat berpengaruh paada kepuasan dan loyalitas pelanggan. Loyalitas nasabah menjadi tujuan utama dalam merencanakan strategi untuk pemasaran jasa perbankan. Kajian penelitian bahwa ada hubungan kepuasan dengan loyalitas pelanggan. Bagian ini juga menjelaskan hubungan antara kualitas pelayanan dan loyalitas pelanggan. Hubungan antara kualitas pelayanan dan loyalitas pelanggan dapat terjalin dalam bentuk langsung atau tidak langsung. Hubungan ini dimediasi dan dikendalikan dari kepuasan pelanggan. Kualitas produk memenuhi kebutuhan nasabah bank cabang BTN Tegal. Hasil penelitian akan memberikan dampak yang signifikan terhadap keberlangsungan cabang BTN Tegal. Dari hasil penelitian ini dapat diketahui peringkat kepuasan nasabah bank BTN cabang Tegal.

\section{LITERATURE REVIEW}

\section{Kualitas Pelayanan}

Kualitas pelayanan merupakan "tingkat kinerja pelayanan dan segala atributnya benarbenar disajikan sesuai dengan harapan konsumen" [5]. Kualitas pelayanan menjadi tanggung jawab penyedia. Pelayanan yang baik. Kualitas pelayanan yang dirasakan oleh konsumen didasarkan pada perbandingan kutipan dari perusahaan jasa, yaitu harapan dan persepsi terhadap aktivitas penyedia pelayanan. Sumber daya manusia dari mengambil keputusan, pemikir, penentu kebijakan dan perencana serta pelaksana paling depan [6]. Kualitas produk ialah produk, pelayanan, orang, proses dan lingkungan dalam memenuhi dan melampaui harapan. Hal tersebut juga dapat dinyatakan bahwa kemampuan untuk menjalankan daya tahan, fungsinya, keandalan, akurasi, kemudahan penggunaan, pemeliharaan, dan atribut berharga lainnya [7].

Kualitas pelayanan harus dilakukan perusahaan agar dapat bertahan dan mendapat kepercayaan pelanggan [8]. Kualitas pelayanan yang diterima atau dirasakan seperti yang dirasakan oleh pelanggan. Pelayanan yang diharapkan dinilai baik dan memuaskan. Pelayanan yang ramah, kamar yang bersih, pelayanan yang layak dan penampilan pegawai bank syariah yang menawan akan peningkatkan kepuasan nasabah terhadap bank tersebut [9].

\section{Kualitas Produk}

Kualitas produk ialah keadaan terkait produk, proses, pelayanan, orang dan lingkungan dalam memenuhi harapan. Kemampuan suatu produk untuk menjalankan fungsinya, termasuk daya tahan, keandalan, akurasi, kemudahan penggunaan, dan pemeliharaan [7].

Parameter kualitas produk meliputi: kinerja (yield), yang berkaitan dengan karakteristik kinerja dasar produk. Umur simpan mengacu pada berapa lama suatu produk dapat digunakan. Produk harus diganti sebelum barang. Memenuhi spesifikasi, d. H Sejauh mana produk memenuhi spesifikasi atau bebas dari cacat. Karakteristik (characteristics) adalah ciri-ciri produk, yang dirancang untuk meningkatkan fungsi, minat konsumen terhadap produk tersebut. Keandalan (reliability) mengacu pada probabilitas bahwa suatu produk dapat memuaskan atau gagal bekerja secara normal dalam jangka waktu tertentu. Estetika mengacu pada penampilan produk. Perceived quality biasanya dianggap sebagai hasil pengukuran tidak langsung, karena konsumen mungkin tidak mengetahui produk yang bersangkutan atau tidak tahu apa-apa tentangnya [10].

\section{Kepuasan Konsumen}

Kepuasan pelanggan adalah indikator terpenting dari loyalitas pelanggan. Nasabah puas dengan pelayanan perbankan syariah akan mengubah menjadi loyalitas dengan dicerminkan pada 
Journal Economics and Management (JECMA), Volume 03, No. 01, Agustus 2021, p. 1-9

membeli orang lain dan mengajak orang lain untuk membeli produk dan pelayanan perbankan syariah. Ketika pelanggan puas dengan nilai suatu produk atau pelayanan, mereka dapat mempertahankan loyalitas mereka dari waktu ke waktu [3].

Kepuasan dapat dikaitkan dengan kesetiaan. Faktor yang mempengruhi kepuasan pelangan salah satunya pelayanan, dapat terjadi ketika perusahaan dan pelanggan merasa puas dalam memberikan produk atau jasa kepada pelanggan [11]. Kepuasan nasabah diukur dari Kualitas produk dan pelayanan yang dibutuhkan nasabah, sehingga jaminan kualitas menjadi salah satu prioritas utama bank. Kepuasan pelanggan terhadap pelayanan erat kaitannya dengan dua faktor utama, yaitu kualitas pelayanan yang diharapkan (expected quality) dan persepsi konsumen terhadap kualitas pelayanan. (Kualitas yang dirasakan). Kepuasan pelanggan harus berjalan seiring dengan loyalitas. Kepuasan nasabah mengacu pada pendapat dan harapan nasabah terhadap pelayanan perbankan [12]. Kerangka pemikiran terdapat pada Gambar 1.

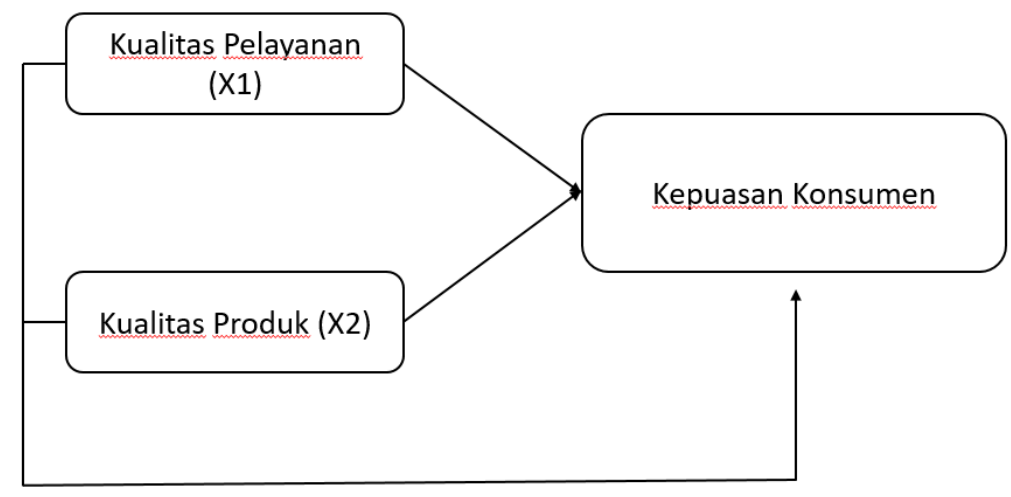

Gambar. 1 Kerangka Pemikiran

\section{Hipotesis}

Ha: Ada pengaruh yang positif dan signifikan antara Kualitas Pelayanan dan Kualitas Produk terhadap tingkat kepuasan Konsumen di Bank BTN Tegal.

H0: Tidak ada pengaruh yang positif dan signifikan antara Kualitas Pelayanan dan Kualitas Produk terhadap tingkat Kepuasan Konsumen di Bank BTN Tegal.

\section{METHODS}

Jenis sumber data penelitian ini adalah data mentah, yaitu data kualitatif yang perlu dikuantifikasi lebih lanjut. Sumber data penelitian ini adalah survei kuisioner nasabah BTN Tegal. Variabel bebas penelitian ini adalah kualitas pelayanan dan kualitas produk, dan variabel terikat penelitian ini adalah kepuasan pelanggan. Populasi dan sampel penelitian ini adalah 100 nasabah BTN Sucursal Tegal. Untuk populasi sebanyak 100 sampel, sampel yang dihasilkan adalah sampel responden. Alat yang digunakan dalam penelitian ini adalah kuesioner yang dibuat oleh penulis untuk mengetahui pengaruh pelayanan dan kualitas produk terhadap kepuasan pelanggan BTN Tegal serta menggunakan software SPSS untuk melakukan regresi linier sederhana untuk mengetahui bagaimana suatu variabel mempengaruhi variabel lain, yaitu pengaruh variabel penjelas terhadap variabel dependen. 
Journal Economics and Management (JECMA), Volume 03, No. 01, Agustus 2021, p. 1-9

\section{RESULTS AND DISCUSSION}

Kualitas pelayanan dan kualitas produk perusahaan sangat penting, karena pada perusahaan perbankan yang menjual produk berupa jasa, kualitas pelayanan sangat penting untuk menilai kepuasan nasabah. Seperti yang ditunjukkan oleh tujuan penelitian ini, tujuannya adalah untuk menguji bagaimana kualitas pelayanan dan kualitas produk mempengaruhi kepuasan nasabah Bank BTN Cabang Tegal.

\section{Uji Validitas dan Reliabilitas}

Berikut ini adalah hasil pengujian validitas dan reliabilitas masing-masing indikator pada masing-masing variabel penelitian.

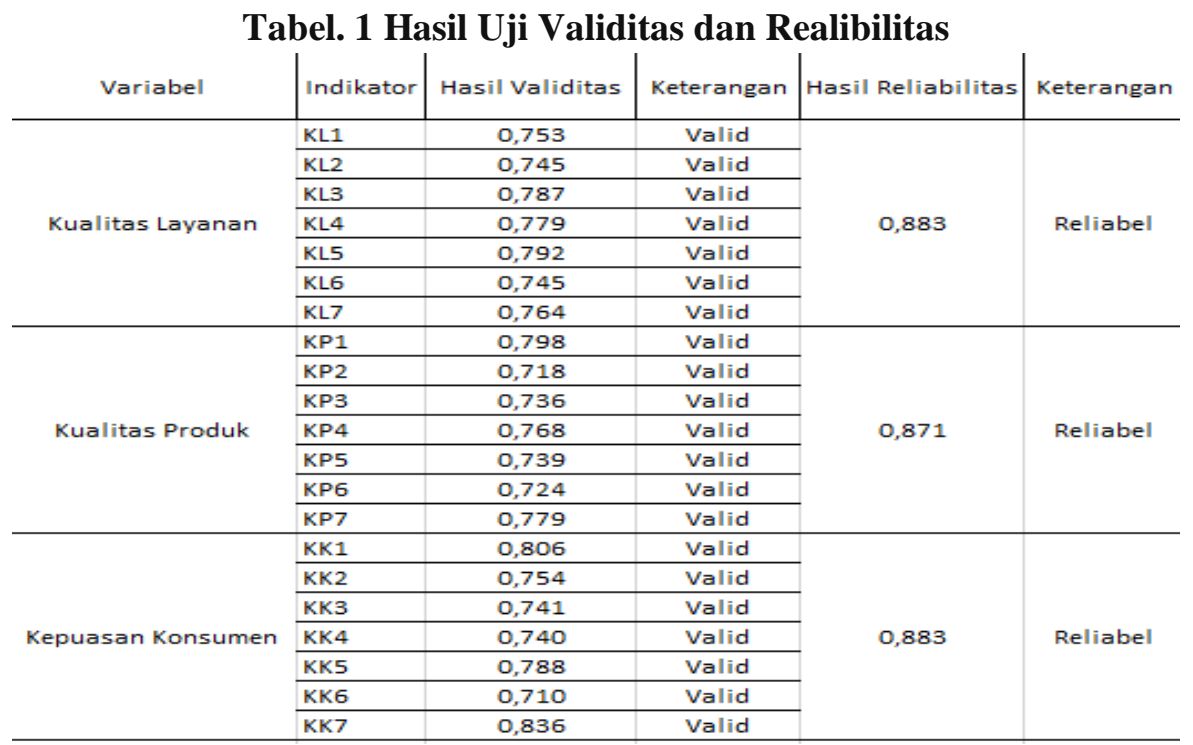

Berdasarkan Tabel 1. maka hasil pengujian dari kualitas pelayanan $\mathrm{X}_{1}$ terhadap kualitas produk $\mathrm{X}_{2}$ terhadap kepuasan pelanggan $\mathrm{Y}$ adalah valid dan reliabel.

\section{Uji Asumsi Klasik}

Uji normalitas digunakan untuk mengetahui apakah data berdistribusi normal. Uji normalitas yang digunakan adalah histogram dan grafik.

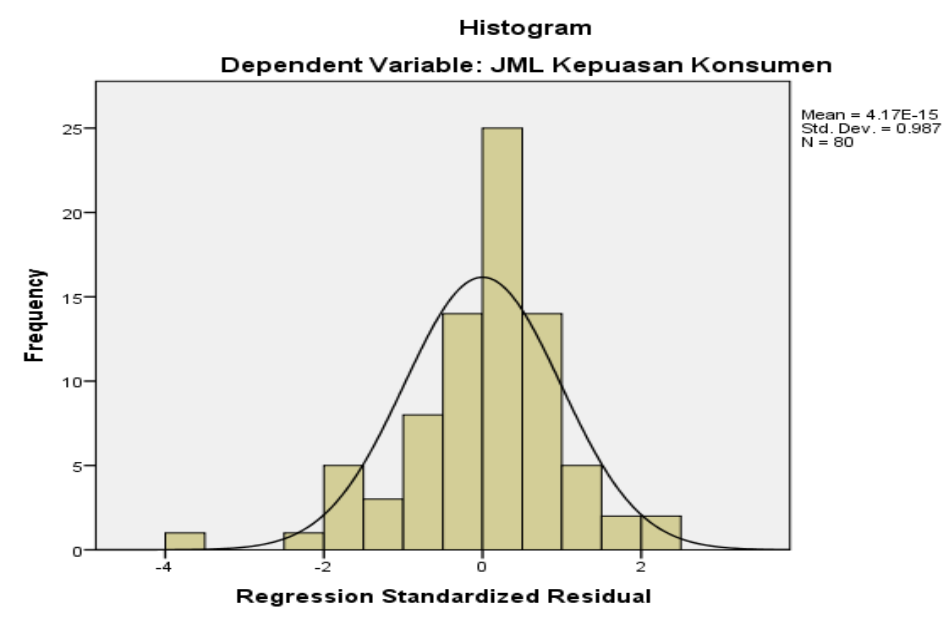

Gambar 2. Histogram 
Journal Economics and Management (JECMA), Volume 03, No. 01, Agustus 2021, p. 1-9

Seperti dapat dilihat dari Gambar 2. grafik menunjukkan pertumbuhan positif dari 4 menjadi 2. Singkatnya, kualitas pelayanan dan kualitas produk mempengaruhi kepuasan nasabah, dan nasabah Bank BTN Tegal merasa puas dengan pelayanan bank.

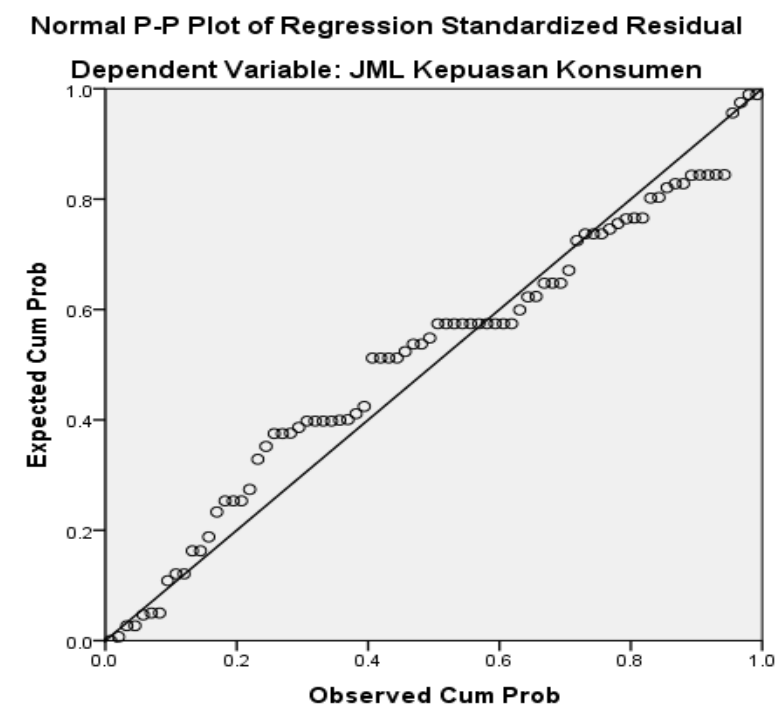

Gambar 3. P-P Plot

Dari Gambar 3 juga menunjukkan grafik pertumbuhan yang stabil, sehingga pada akhirnya masyarakat puas dengan pelayanan dan kualitas produk, seperti hasil kerja BTN cabang Tegal.

\section{Uji Multikolinieritas}

Jika VIF lebih kecil dari $\langle 10\rangle 0,1$, maka tidak terjadi multikolinearitas, sebaliknya jika VIF lebih besar dari $>10$ dan nilai toleransi lebih besar dari $<0,1$, maka terjadi multikolinearitas.

Tabel 2. Hasil Uji Multikolinieritas

\begin{tabular}{|c|c|c|c|c|c|c|c|c|}
\hline \multicolumn{9}{|c|}{ Coefficients ${ }^{a}$} \\
\hline & & \multicolumn{2}{|c|}{ Unstandardized Coefficients } & \multirow{2}{*}{$\begin{array}{c}\text { Standardized } \\
\text { Coefficients } \\
\text { Beta } \\
\end{array}$} & \multirow[b]{2}{*}{$\mathrm{t}$} & \multirow[b]{2}{*}{ Sig. } & \multicolumn{2}{|c|}{ Collinearity Statistics } \\
\hline \multicolumn{2}{|c|}{ Model } & B & Std. Error & & & & Tolerance & VIF \\
\hline \multirow[t]{3}{*}{1} & (Constant) & 1.632 & 1.078 & & 1.514 & .134 & & \\
\hline & JML Kualitas Layanan & 291 & .092 & .316 & 3.153 & .002 & .137 & 7.288 \\
\hline & JML Kualitas Produk & 644 & .100 & 644 & 6.420 & .000 & .137 & 7.288 \\
\hline
\end{tabular}

a. Dependent Variable: JML Kepuasan Konsumen

Dapat dilihat dari Tabel 2 bahwa nilai variabel VIF $\left(\mathrm{X}_{1}\right)$ kualitas pelayanan dan variabel $\left(\mathrm{X}_{2}\right)$ kualitas produk adalah $7,288<10>0,1$. Oleh karena itu, tidak ada multikolinearitas dalam data.

\section{Uji Heteroskedastisitas}

Uji heteroskedastisitas ini menganalisis pola titik-titik pada grafik sebar regresi. Ketika ada pola tertentu, seperti titik yang membentuk pola teratur, maka akan muncul heteroskedastisitas. Namun, jika tidak ada pola yang jelas, misalnya B. Titik yang memanjang ke atas dan ke bawah sepanjang sumbu Y di 0 tidak heteroskedastis. 
Journal Economics and Management (JECMA), Volume 03, No. 01, Agustus 2021, p. 1-9

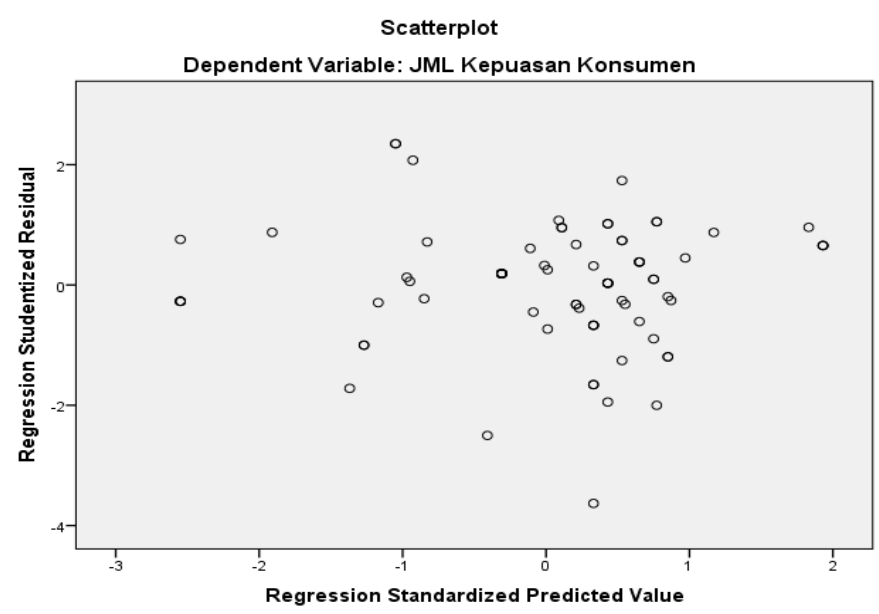

Gambar 4. Hasil Uji Heterosdasitisitas

Dari Gambar 4. terdapat anggaran yang jelas, titik-titiknya membentang pada permukaan dan bawah, sebagai akibatnya bisa disimpulkan bahwa uji nir mengalami heteroskedastisitas.

\section{Uji Hipotesis}

Pengujian Hipotesis Pengujian hipotesis dilakukan dengan menggunakan analisis regresi linier berganda yang bertujuan untuk memprediksi derajat hubungan antara variabel bebas yaitu: kualitas pelayanan $\left(\mathrm{X}_{1}\right)$, kualitas produk $\left(\mathrm{X}_{2}\right)$, dan kepuasan pelanggan $(\mathrm{Y})$.

\section{Uji Analisis Regresi Berganda (uji t)}

Uji analisis regresi berganda (uji-t) Jika simbol $0>0,05$ maka tidak ada pengaruh.

Tabel 3. Hasil Uji Analisis Regresi Berganda (Uji t)

\begin{tabular}{|c|c|c|c|c|c|c|}
\hline \multicolumn{7}{|c|}{ Coefficients ${ }^{a}$} \\
\hline & & \multicolumn{2}{|c|}{ Unstandardized Coefficients } & \multirow{2}{*}{$\begin{array}{c}\text { Standardized } \\
\text { Coefficients } \\
\text { Beta } \\
\end{array}$} & \multirow[b]{2}{*}{$\mathrm{t}$} & \multirow[b]{2}{*}{ Sig. } \\
\hline \multicolumn{2}{|c|}{ Model } & $\mathrm{B}$ & Std. Error & & & \\
\hline \multirow[t]{3}{*}{1} & (Constant) & 1.632 & 1.078 & & 1.514 & .134 \\
\hline & JML Kualitas Layanan & .291 & .092 & .316 & 3.153 & .002 \\
\hline & JML Kualitas Produk & .644 & .100 & .644 & 6.420 & .000 \\
\hline
\end{tabular}

a. Dependent Variable: JML Kepuasan Konsumen

Berdasarkan Tabel 3 menunjukkan kualitas pelayanan $X_{1}$ adalah $0,002<0,05$, dan kualitas produk $\mathrm{X}_{2}$ adalah $0,000<0,05$. Hal ini berarti kualitas pelayanan dan produk berpengaruh terhadap kepuasan pelanggan.

\section{Uji Analisis Regresi Berganda (uji f)}

Jika sign $<0,05$ maka terdapat pengaruh, namun sebaliknya jika sign $>0,05$ maka tidak terdapat pengaruh. 
Journal Economics and Management (JECMA), Volume 03, No. 01, Agustus 2021, p. 1-9

Tabel 4. Hasil Uji Analisis Regresi Berganda (Uji f)

\begin{tabular}{|l|l|r|r|r|r|r|}
\hline \multicolumn{7}{|l|}{ ANOVA $^{\text {a }}$} \\
\hline \multirow{2}{*}{$\begin{array}{l}\text { Model } \\
1\end{array}$} & Sum of Squares & df & Mean Square & F & \multicolumn{1}{c|}{ Sig. } \\
\cline { 2 - 8 } & Regression & 674.148 & 2 & 337.074 & 323.464 & $.000^{\mathrm{b}}$ \\
\cline { 2 - 8 } & Residual & 80.240 & 77 & 1.042 & & \\
\cline { 2 - 7 } & Total & 754.388 & 79 & & & \\
\hline
\end{tabular}

a. Dependent Variable: JML Kepuasan Konsumen

b. Predictors: (Constant), JML Kualitas Produk, JML Kualitas Layanan

Berdasarkan Tabel 4. menunjukkan hasil uji regresi berganda dengan nilai adalah 0,000 $<0,05$, jadi dapat dikatakan terdapat pengaruh yang signifikan antara nilai kualitas pelayanan $\mathrm{X}_{1}$ dan produk $\mathrm{X}_{2}$ terhadap kepuasan pelanggan.

\section{CONCLUSION}

Berdasarkan hasil penelitian menunjukkan bahwa BTN Cabang Tegal memiliki kepuasan pelanggan tinggi terhadap tingkat pelayanan dan kualitas produk yang diberikan. BTN Cabang Tegal melayani nasabah dengan baik, dan rapi, sehingga sikap nasabah maupun pegawai bank BTN cabang Tegal dapat diterima. Berdasarkan penelitian yang dilakukan peneliti menggunakan SPSS untuk menguji variabel dan perhitungan. Dari verifikasi dan reliabilitas hingga pengujian hipotesis regresi berganda (t) dan (f). Oleh karena itu, nilai signifikansinya adalah 0,000 <0,05. Sehingga variabel kualitas pelayanan $\left(\mathrm{X}_{1}\right)$ dan produk $\left(\mathrm{X}_{2}\right)$ dapat dikatakan berpengaruh terhadap kepuasan konsumen (Y).

\section{REFERENCES}

[1] Kusuma Wijayanto, "Pengaruh Kualitas Pelayanan terhadap Kepuasan dan Loyalitas Nasabah Bank," J. Manajemen dan Pemasaran. Jasa, vol. 17, no. 1, p. 8, 2015, doi: 10.25105/jmpj.v1i2.1211.

[2] A. Kristiana, M. Syaifulloh, and S. B. Riono, "Analisa faktor faktor yang mempengaruhi kinerja karyawan di rsu islami mutiara bunda," J. Manaj. dan Akunt., vol. 16, no. 1, pp. 104-114, 2021.

[3] Umar, H. (2000). Riset pemasaran dan perilaku konsumen, Jakarta: Kompas Gramedia.

[4] Wibowati. (2020). Pengaruh Kualitas Pelayanan Terhadap Kepuasan Pelanggan Pada Pt Muarakati Baru Satu Palembang. Volume 6.

[5] Bryan Fauzi Rivaldy, H. Pengaruh Strategi Promosi, Kualita Produc dan Kualitas Pelayanan terhadap Kepuasan Pelanggan.

[6] B. A. P. Muhammad Syaifulloh, "Analisis Profesionalisme Guru, Diklat dan Prestasi Guru terhadap Kualitas Pendidikan Pada Sekbin 3 UPTD Pendidikan Kecamatan Brebes Kabupaten Brebes," JPSD, vol. 3, no. 1, pp. 17-25, 2017, doi: 10.1017/CBO9781107415324.004.

[7] Winda Jaya, 2019, Pengaruh Kualitas Pelayanan, Kualitas Produk, Harga, Dan Lokasi Terhadap Kepuasan Konsumen ( Studi Kasus Pada Konsumen Kafe Family Kopi Di Malang).

[8] M. S. Khalid Iskandar, Aris Armunanto, "Value: Jurnal Manajemen dan Akuntansi Value: Jurnal Manajemen dan Akuntansi Volume 16 Nomor 1," Value J. Manaj. dan Akunt., vol. 16, no. 1, pp. 24-34, 2021.

[9] Zakiy, M, 2017, Pengaruh Kwalitas Pelayanan Terhadap Loyalita Nasabah Bank Syariah Dengan Kepuasan Nasabah Sebagai Variabel Intervening. 
Journal Economics and Management (JECMA), Volume 03, No. 01, Agustus 2021, p. 1-9

[10] Basrah Saidani, S. A, 2012, Pegnaruh Kualitas Produk Dan Kualita Laynan Terhadap Kepuasan Konsumen Dan Minat Beli Pada Ranch Market .

[11] Akmal Muhammad Fauzan, S. S, 2019, Pegnaruh Kualitas Pelayanan Dan Haga Terhadap Kepuasn Konsumen (Survei pada Mahasiswa Pengguna Gojek di Universitas Slamet Riyadi Surakarta).

[12] Hidayat, R, 2019, Pengaruh Kualitas Pelayanan, Kualitas Produc dan Nilai Nasabah Terhadp Kepuasan dan Loyalitas Nasabah Bank Mandiri) Jurusan Teknik Industri, Universitas Trunojoyo Madura. 